\title{
Comparison of Net Global Warming Potential and Greenhouse Gas Intensity Affected by Management Practices in Two Dryland Cropping Sites
}

\author{
Upendra M. Sainju \\ USDA, Agricultural Research Service, Northern Great Plains Agricultural Research Laboratory, Sidney, Montana, \\ USA \\ Email: upendra.sainju@ars.usda.gov
}

Received 4 April 2015; accepted 15 September 2015; published 18 September 2015

Copyright (C) 2015 by author and Scientific Research Publishing Inc. This work is licensed under the Creative Commons Attribution International License (CC BY). http://creativecommons.org/licenses/by/4.0/

(c) (i) Open Access

\section{Abstract}

Little is known about the effect of management practices on net global warming potential (GWP) and greenhouse gas intensity (GHGI) that account for all sources and sinks of greenhouse gas (GHG) emissions in dryland cropping systems. The objective of this study was to compare the effect of a combination of tillage, cropping system, and $\mathrm{N}$ fertilization on GWP and GHGI under dryland cropping systems with various soil and climatic conditions from 2008 to 2011 in western North Dakota and eastern Montana, USA. Treatments in western North Dakota with sandy loam soil and $373 \mathrm{~mm}$ annual precipitation were conventional till malt barley (Hordeum vulgarie L.) with $67 \mathrm{~kg} \mathrm{~N} \mathrm{ha-1}$

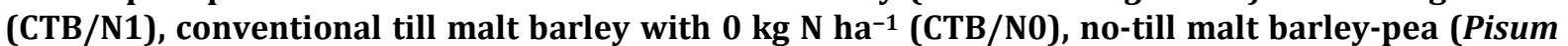

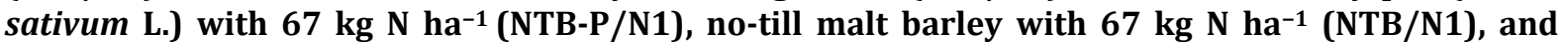
no-till malt barley with $0 \mathrm{~kg} \mathrm{~N} \mathrm{ha-1} \mathrm{(NTB/NO).} \mathrm{In} \mathrm{eastern} \mathrm{Montana} \mathrm{with} \mathrm{loam} \mathrm{soil} \mathrm{and} 350 \mathrm{~mm}$ annual precipitation, treatments were conventional till malt barley-fallow with $80 \mathrm{~kg} \mathrm{~N} \mathrm{ha}^{-1}$ (CTB-F/N1), conventional till malt barley-fallow with $0 \mathrm{~kg} \mathrm{~N}^{\mathrm{N} \mathrm{a}^{-1}}$ (CTB-F/N0), no-till malt bar-

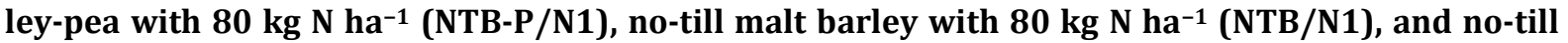

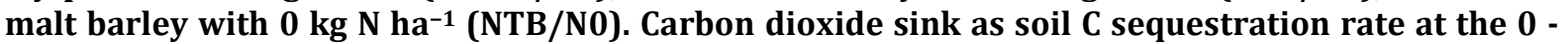
$10 \mathrm{~cm}$ depth was greater in NTB-P/N1 and NTB/N1 than the other treatments at both sites and greater in eastern Montana than western North Dakota. Carbon dioxide sources were greater with $\mathbf{N}$ fertilization than without and greater with conventional till than no-till. Soil total annual $\mathrm{N}_{2} \mathrm{O}$ and $\mathrm{CH}_{4}$ fluxes varied among treatments, years, and locations. Net GWP and GHGI were lower in NTB-P/N1 than the other treatments in western North Dakota and lower in NTB-P/N1 and NTB/N1 than the other treatments in eastern Montana. Net GWP across similar treatments was lower in eastern Montana than western North Dakota, but GHGI was similar. Annualized crop yield was greater in the treatments with $\mathbf{N}$ fertilization than without. Because of greater grain yield but low- 
er GWP and GHGI, no-till malt barley-pea rotation with adequate $\mathbf{N}$ fertilization can be used as a robust management practice to mitigate net GHG emissions while sustaining dryland crop yields, regardless of soil and climatic conditions. Loam soil reduced GWP and crop yields compared with sandy loam soil.

\section{Keywords}

\section{Carbon Sequestration, Crop Yields, Dryland Cropping Systems, Greenhouse Gas Mitigation, Management Practices}

\section{Introduction}

Agricultural practices produce three soil greenhouse gases (GHGs- $\mathrm{CO}_{2}, \mathrm{~N}_{2} \mathrm{O}$, and $\mathrm{CH}_{4}$ ) that significantly contribute to radiative forcing of earth's atmosphere for global warming [1]-[3]. While soil C sequestration acts as the sink for GHGs, [1] [3] [4], chemical inputs used for increasing crop yields and residue returned to the soil, such as $\mathrm{N}$, $\mathrm{P}$, and $\mathrm{K}$ fertilizations and herbicide and pesticide applications, can produce $\mathrm{CO}_{2}$, thereby reducing the GHG mitigation potential [5]. Manufacture and transportation of fertilizers that are applied in large quantities, such as $\mathrm{N}$ fertilizer, and fuel used in machines for farm operations can produce $\mathrm{CO}_{2}$ that can counteract the mitigation efforts [1] [6]. The balance between $\mathrm{C}$ sequestration and $\mathrm{N}_{2} \mathrm{O}$ and $\mathrm{CH}_{4}$ emissions as well as $\mathrm{CO}_{2}$ emissions from chemical inputs and farm operations controls net global warming potential (GWP) and greenhouse gas intensity (GHGI) [1]-[3]. As a result, all sources and sinks of GHGs in the agroecosystem should be considered while evaluating the effect of agricultural practices on GHG emissions [1].

Some of the novel management practices, such as no-till, diversified crop rotation, increased cropping intensity, and reduced $\mathrm{N}$ fertilization rate, can increase soil C sequestration and mitigate GHG emissions [3] [7] [8]. Soil organic $\mathrm{C}$ (SOC) sequestration can be increased by using the no-till system which reduces soil disturbance, residue incorporation, and microbial activity and therefore lowers $\mathrm{CO}_{2}$ emissions compared with the conventional system [3] [9]. Greater amount of crop residue returned to soil due to increased cropping intensity, diversified crop rotation, and $\mathrm{N}$ fertilization can increase SOC and reduce GHG emissions compared with fallow, monocropping, and no $\mathrm{N}$ fertilization [3] [10] [11]. Nitrogen fertilization primarily stimulates $\mathrm{N}_{2} \mathrm{O}$ emissions [3] [12] [13], but has a variable effect on $\mathrm{CO}_{2}$ and $\mathrm{CH}_{4}$ emissions [11] [14] [15]. It is expected that a combination of management practices that includes no-till, diversified crop rotation, and reduced $\mathrm{N}$ fertilization rate might further enhance SOC sequestration and mitigate net GHG emissions without influencing crop yields compared with individual practices. Increased C sequestration also helps to improve soil quality and productivity through enhanced soil water-nutrients-crop yield relationships [16] [17] and can serve as an additional source of income for farmers [18] [19].

Soil and climatic conditions can also affect C sequestration and GHG emissions [3] [17] [20]. Net GWP is usually higher in tropical than in temperate regions due to increased organic matter mineralization [8]. Mosier et al. [2] reported greater net GWP in Michigan with $900 \mathrm{~mm}$ precipitation than in Colorado with $420 \mathrm{~mm}$, although both sites had loam soils under dryland cropping systems. Similarly, Sainju et al. [17] [20] found greater $\mathrm{CO}_{2}$ emissions but lower SOC due to increased organic matter mineralization in western North Dakota with sandy loam soil and $373 \mathrm{~mm}$ precipitation than in eastern Montana with loam soil and $350 \mathrm{~mm}$ precipitation.

Information on the effect of combined management practices on net GWP and GHGI under various soil and climatic conditions is scanty. This study compared net GWP and GHGI as affected by management practices from two dryland cropping systems in Nesson Valley, North Dakota and Sidney, Montana, USA. The objectives of this study were to 1) evaluate the effects of combinations of tillage, cropping systems, and $\mathrm{N}$ fertilization rates on net GWP and GHGI from 2008 to 2011 at two dryland cropping sites in the northern Great Plains, USA, 2) compare net GWP and GHGI using similar treatments between the sites with different soil and climatic conditions, and 3) identify management practices that mitigate net GHG emissions while sustaining crop yields. It was hypothesized that no-till malt barley-pea rotation with $\mathrm{N}$ fertilization could reduce net GWP and GHGI compared with the traditional conventional till malt barley or conventional till malt barley-fallow with or without $\mathrm{N}$ fertilization and that the site with finer soil texture would reduce net GWP and GHGI compared with the site with coarser texture. 


\section{Materials and Methods}

\subsection{Experimental Sites, Treatments, and Crop Management}

The experiment was described in detail by Sainju et al. [20]. Briefly, in Nesson Valley, western North Dakota, the experiment was conducted in a Lihen sandy loam (sandy, mixed, frigid, EnticHaplustoll) from 2008 to 2011 in a land converted from Conservation Reserve Program grassland to cropland in 2005 in Nesson Valley $\left(48.1^{\circ} \mathrm{N}\right.$, $103.1^{\circ} \mathrm{W}$ ), western North Dakota, USA (Figure 1). The soil had $720 \mathrm{~g} \cdot \mathrm{kg}^{-1}$ sand, $120 \mathrm{~g} \cdot \mathrm{kg}^{-1}$ silt, $160 \mathrm{~g} \cdot \mathrm{kg}^{-1} \mathrm{clay}$, $7.7 \mathrm{pH}$, and $10.9 \mathrm{~g} \cdot \mathrm{kg}^{-1} \mathrm{SOC}$ at the $0-20 \mathrm{~cm}$ depth before the initiation of the experiment in April 2005. Average (30 yr) air temperature in the site ranged from $-5^{\circ} \mathrm{C}$ in January to $32^{\circ} \mathrm{C}$ in July-August and mean annual precipitation was $373 \mathrm{~mm}$. Treatments were two irrigation practices (irrigated and non-irrigated) as the main plot and five cropping systems (conventional-till malt barley with 67 to $134 \mathrm{~kg} \mathrm{~N} \mathrm{ha}^{-1}$ [CTB/N1], conventional-till malt barley with $0 \mathrm{~kg} \mathrm{~N}^{-1}{ }^{-1}$ [CTB/N0], no-till malt barley-pea with 67 to $134 \mathrm{~kg} \mathrm{~N} \mathrm{ha}^{-1}$ [NTB-P/N1], no-till malt barley with 67 to $134 \mathrm{~kg} \mathrm{~N}$ ha $^{-1}$ [NTB/N1], and no-till malt barley with $0 \mathrm{~kg} \mathrm{~N} \mathrm{ha}^{-1}$ [NTB/N0]) as split-plot treatments arranged in a randomized complete block with three replications. The NTB-P/N1 included both malt barley and pea phases of the crop rotation in every year. The CTB/N1 was the traditional farming system for both irrigated and non-irrigated malt barley production in the experimental site. Recommended $\mathrm{N}$ rates which included both fertilizer and soil residual $\mathrm{N}$ for irrigated and non-irrigated malt barley were $134 \mathrm{and} 67 \mathrm{~kg}$ $\mathrm{N} \mathrm{ha}^{-1}$, respectively. To determine the amount of fertilizer $\mathrm{N}$ as urea $(46 \% \mathrm{~N})$ applied to irrigated and non-irrigated malt barley in each year, soil $\mathrm{NO}_{3}-\mathrm{N}$ content to a depth of $60 \mathrm{~cm}$ in samples collected in the autumn of the previous year was deducted from recommended $\mathrm{N}$ rates. No $\mathrm{N}$ fertilizer was applied to pea. Malt barley and pea were planted in April and harvested in August 2005 to 2011. After grain harvest, crop residue (stems and leaves) were returned to the soil. For this study, only cropping systems in the non-irrigated practice were used.

In Sidney, eastern Montana, the site had mean monthly air temperature ranging from $-8^{\circ} \mathrm{C}$ in January to $32^{\circ} \mathrm{C}$ in July and August and mean annual precipitation (105-yr average) of $350 \mathrm{~mm}$ (Figure 1). The soil was a Williams loam (fine-loamy, mixed, superactive, frigid, Typic Argiustolls) with $350 \mathrm{~g} \cdot \mathrm{kg}^{-1}$ sand, $325 \mathrm{~g} \cdot \mathrm{kg}^{-1}$ silt, 325 $\mathrm{g} \cdot \mathrm{kg}^{-1}$ clay, $11.3 \mathrm{~g} \cdot \mathrm{kg}^{-1} \mathrm{SOC}$, and $7.2 \mathrm{pH}$ at the $0-20 \mathrm{~cm}$ depth. Previous cropping system for the past 6 yr was conventional till spring wheat (Triticum aestivum L.)-fallow-safflower (Carthamus tinctorius L.). Treatments included conventional till malt barley-fallow with 0 (CTB-F/N0) and $80 \mathrm{~kg} \mathrm{~N} \mathrm{ha}^{-1}$ (CTB-F/N1), no-till malt barleypea with 0 (NTB-P/N0) and $80 \mathrm{~kg} \mathrm{~N} h^{-1}$ (NTB-P/N1), and no-till malt barley with 0 (NTB/N0) and $80 \mathrm{~kg} \mathrm{~N} \mathrm{ha}^{-1}$

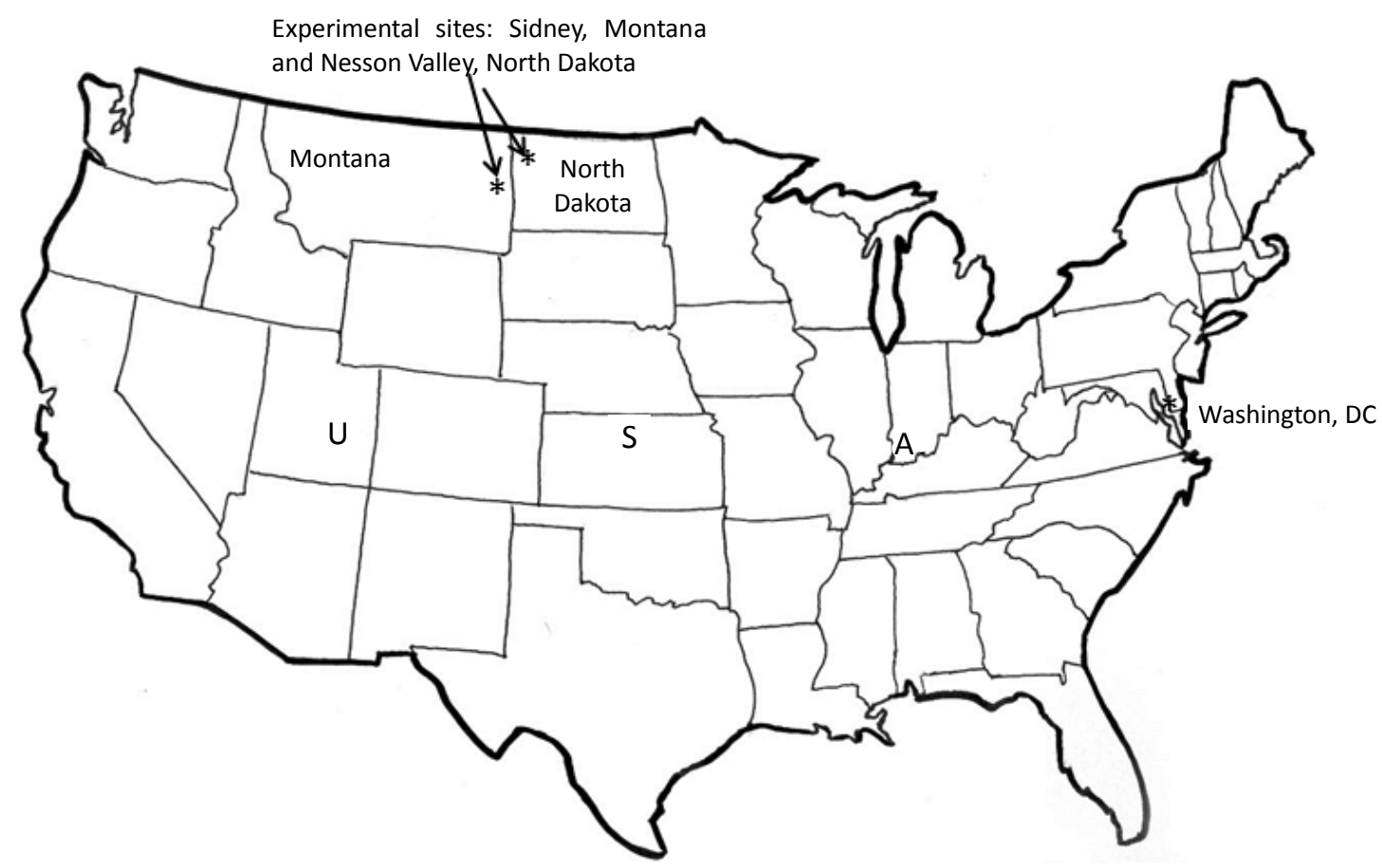

Figure 1. Location of the experimental sites in USA: Sidney, Montana and Nesson Valley, North Dakota. 
(NTB/N1). For this study, all treatments, except NTB-P/N0, were included. Treatments were arranged in randomized complete block with three replications. Each phase of the cropping sequence that included malt barley and pea in NTB-P/N1 and malt barley and fallow in CTB-F/N1 and CTB-F/N0 was present in every year. The CTB-F/N1 was the traditional system. As with Nesson Valley, recommended $\mathrm{N}$ rate $\left(80 \mathrm{~kg} \mathrm{~N} \mathrm{ha}^{-1}\right)$ included fertilizer $\mathrm{N}$ as urea and soil residual $\mathrm{NO}_{3}-\mathrm{N}$ content which was determined in soil samples collected to a depth of $60 \mathrm{~cm}$ in the autumn of the previous year. No $\mathrm{N}$ fertilizer was applied to pea and the fallow phases. Malt barley and pea were planted in April and harvested in August 2006 to 2011. After grain harvest, crop residues were returned to the soil.

\subsection{Gas, Soil, and Crop Measurements}

At both sites, $\mathrm{N}_{2} \mathrm{O}$ and $\mathrm{CH}_{4}$ fluxes were measured with static, vented chambers at 3 to $14 \mathrm{~d}$ intervals from March to November 2008 to 2011 after analyzing concentrations of gases using a gas chromatograph. Total annual fluxes were determined by adding the missing values of winter (December-February) emissions to the cumulative flux from nearest locations [4] [12]. The $\mathrm{CO}_{2}$ equivalents of $\mathrm{N}_{2} \mathrm{O}$ and $\mathrm{CH}_{4}$ fluxes were calculated by multiplying their values by 298 and 25, respectively [21]. Since $\mathrm{N}$ fertilization can produce $\mathrm{CO}_{2}$ and $\mathrm{N}_{2} \mathrm{O}$ directly (manufacture, transport, and application of $\mathrm{N}$ fertilizer to crops) and indirectly $\left(\mathrm{NH}_{4}\right.$ volatilization, $\mathrm{N}$ leaching, and urea hydrolysis in the soil), $\mathrm{CO}_{2}$ equivalents of GHG emissions due to $\mathrm{N}$ fertilization were estimated by adding direct and indirect emissions [10] [22] (Table 1). The $\mathrm{CO}_{2}$ equivalent of fuel used for farm operations (tillage, planting, $\mathrm{P}$ and $\mathrm{K}$ fertilization, herbicide and pesticide applications, and harvest) and machine manufacture (Table 2) was estimated as shown by [23]. The values were based on the total amount of $\mathrm{CO}_{2}$ emitted per liter of fuel and number of hours the machine was used for operations.

For calculating the $\mathrm{CO}_{2}$ equivalent of $\mathrm{C}$ sequestration rates, soil samples were collected from the $0-10 \mathrm{~cm}$ depth after crop harvest in October 2006 to 2011 at both sites. Samples were collected from five locations from central rows within the plot with a hydraulic probe (3.5 cm inside diameter), composited, air-dried, and sieved to

Table 1. Carbon dioxide equivalents of N fertilization to crops in various management practices from 2008 to 2011 in Nesson Valley, North Dakota and Sidney, Montana.

\begin{tabular}{|c|c|c|c|c|c|}
\hline \multirow{2}{*}{ Management practice $^{\mathrm{a}}$} & \multicolumn{5}{|c|}{$\mathrm{N}$ fertilization $\left(\mathrm{kg} \mathrm{CO}_{2} \text { eq. } \mathrm{ha}^{-1} \cdot \mathrm{yr}^{-1}\right)^{\mathrm{b}}$} \\
\hline & 2008 & 2009 & 2010 & 2011 & Total \\
\hline \multicolumn{6}{|l|}{ Nesson Valley } \\
\hline CTB/N1 & 235 & 235 & 235 & 235 & 940 \\
\hline CTB/N0 & 0 & 0 & 0 & 0 & 0 \\
\hline NTB-P/N1 & 189 & 146 & 146 & 146 & 627 \\
\hline NTB/N1 & 235 & 235 & 235 & 235 & 940 \\
\hline NTB/N0 & 0 & 0 & 0 & 0 & 0 \\
\hline \multicolumn{6}{|l|}{ Sidney } \\
\hline CTB-F/N1 & 0 & 256 & 67 & 205 & 528 \\
\hline CTB-F/N0 & 0 & 0 & 0 & 0 & 0 \\
\hline NTB-P/N1 & 0 & 227 & 239 & 260 & 726 \\
\hline NTB/N1 & 84 & 231 & 243 & 264 & 822 \\
\hline NTB/N0 & 0 & 0 & 0 & 0 & 0 \\
\hline
\end{tabular}

${ }^{a}$ Management practices for Nesson valley were CTB/N1, conventional till malt barley with $67 \mathrm{~kg} \mathrm{~N}^{-1}$; CTB/N0, conventional till malt barley with $0 \mathrm{~kg} \mathrm{~N} \mathrm{ha}^{-1}$; NTB-P/N1, no-till malt barley-pea with $67 \mathrm{~kg} \mathrm{~N} \mathrm{ha}^{-1}$; NTB/N1, no-till malt barley with $67 \mathrm{~kg} \mathrm{~N} \mathrm{ha}{ }^{-1}$; and NTB/N0, no-till malt barley with $0 \mathrm{~kg} \mathrm{~N} \mathrm{ha}^{-1}$. For Sidney, management practices were CTB-F/N1, conventional till malt barley-fallow with $80 \mathrm{~kg} \mathrm{~N} \mathrm{ha}{ }^{-1}$; CTB-F/N0, conventional till malt barley-fallow with $0 \mathrm{~kg} \mathrm{~N}^{-1}$; NTB-P/N1, no-till malt barley-pea with $80 \mathrm{~kg} \mathrm{~N} \mathrm{ha}^{-1}$; NTB/N1, no-till malt barley with $80 \mathrm{~kg} \mathrm{~N}$ ha ${ }^{-1}$; and $\mathrm{NTB} / \mathrm{N} 0$, no-till malt barley with $0 \mathrm{~kg} \mathrm{~N} \mathrm{ha}^{-1}$. ${ }^{\mathrm{b}}$ Includes direct and indirect sources of $\mathrm{N}$ fertilization. Direct source of $\mathrm{N}$ fertilization (production, transportation, and application of $\mathrm{N}$ fertilizer) $=46 \mathrm{~kg} \mathrm{CO}_{2} \mathrm{ha}^{-1}$ for application $+3.0 \mathrm{~kg} \mathrm{CO}_{2} \mathrm{~kg}^{-1} \mathrm{~N}$ applied [10]. Indirect source of N fertilization $\left(\mathrm{NH}_{4}\right.$ volatilization, $\mathrm{N}$ leaching, and urea hydrolysis $)=0.4 \%$ of applied $\mathrm{N}$ fertilizer [22]. 
Table 2. Carbon dioxide equivalents of farm operations used for crop production in various management practices from 2008 to 2011 in Nesson Valley, North Dakota and Sidney, Montana.

\begin{tabular}{|c|c|c|c|c|c|c|c|}
\hline \multirow{2}{*}{$\begin{array}{l}\text { Management } \\
\text { practice }^{\mathrm{b}}\end{array}$} & \multirow{2}{*}{$\begin{array}{l}\text { Chisel } \\
\text { tillage }\end{array}$} & \multicolumn{6}{|c|}{ Farm operations $\left(\mathrm{kg} \mathrm{CO}_{2} \text { eq. } \mathrm{ha}^{-1} \cdot \mathrm{yr}^{-1}\right)^{\mathrm{a}}$} \\
\hline & & $\begin{array}{l}\text { Crop planting and } \\
\mathrm{P} \text { and } \mathrm{K} \text { fertilization }\end{array}$ & $\begin{array}{l}\mathrm{P} \text { and } \mathrm{K} \text { fertilizer } \\
\text { production }\end{array}$ & $\begin{array}{l}\text { Herbicide production } \\
\text { and application }\end{array}$ & Crop harvest & $\begin{array}{l}\text { Farm machinery } \\
\text { production }\end{array}$ & Total \\
\hline \multicolumn{8}{|l|}{ Nesson Valley } \\
\hline $\mathrm{CTB} / \mathrm{N} 1$ & 58 & 12 & 36 & 28 & 27 & 21 & 182 \\
\hline CTB/N0 & 58 & 12 & 36 & 28 & 27 & 21 & 182 \\
\hline NTB-P/N1 & 0 & 12 & 36 & 28 & 27 & 21 & 124 \\
\hline NTB/N1 & 0 & 12 & 36 & 28 & 27 & 21 & 124 \\
\hline NTB/N0 & 0 & 12 & 36 & 28 & 27 & 21 & 124 \\
\hline \multicolumn{8}{|l|}{ Sidney } \\
\hline CTB-F/N1 & 58 & 12 & 36 & 28 & 27 & 21 & 182 \\
\hline CTB-F/N0 & 58 & 12 & 36 & 28 & 27 & 21 & 182 \\
\hline NTB-P/N1 & 0 & 12 & 36 & 28 & 27 & 21 & 124 \\
\hline NTB/N1 & 0 & 12 & 36 & 28 & 27 & 21 & 124 \\
\hline NTB/N0 & 0 & 12 & 36 & 28 & 27 & 21 & 124 \\
\hline
\end{tabular}

${ }^{a}$ Estimated as shown by [23]. ' ${ }^{b}$ Management practices for Nesson valley were CTB/N1, conventional till malt barley with $67 \mathrm{~kg}$ N ha ${ }^{-1}$; CTB/N0, conventional till malt barley with $0 \mathrm{~kg} \mathrm{~N} \mathrm{ha}^{-1}$; NTB-P/N1, no-till malt barley-pea with $67 \mathrm{~kg} \mathrm{~N} \mathrm{ha}^{-1}$; NTB/N1, no-till malt barley with 67 kg N ha ${ }^{-1}$; and NTB/N0, no-till malt barley with $0 \mathrm{~kg} \mathrm{~N} \mathrm{ha}^{-1}$. For Sidney, management practices were CTB-F/N1, conventional till malt barley-fallow with $80 \mathrm{~kg}$ $\mathrm{N} \mathrm{ha}^{-1}$; CTB-F/N0, conventional till malt barley-fallow with $0 \mathrm{~kg} \mathrm{~N} \mathrm{ha}^{-1}$; NTB-P/N1, no-till malt barley-pea with $80 \mathrm{~kg} \mathrm{~N}$ ha ${ }^{-1}$; NTB/N1, no-till malt barley with $80 \mathrm{~kg} \mathrm{~N}^{-1}$; and NTB/N0, no-till malt barley with $0 \mathrm{~kg} \mathrm{~N}^{-1}$.

$2 \mathrm{~mm}$. The SOC concentration ( $\mathrm{g} \mathrm{C} \mathrm{kg}^{-1}$ ) in the sample was determined using a high induction furnace $\mathrm{C}$ and $\mathrm{N}$ analyzer (LECO, St. Joseph, MI) after grinding a subsample to $0.5 \mathrm{~mm}$ and pretreating it with $5 \% \mathrm{H}_{2} \mathrm{SO}_{3}$ to remove inorganic $\mathrm{C}$ [24]. The SOC content $\left(\mathrm{Mg} \mathrm{C} \mathrm{ha}^{-1}\right)$ was determined by multiplying its concentration by the bulk density of the soil measured at the time of sample collection (weight of oven-dried soil at $105^{\circ} \mathrm{C}$ divided by the volume of the core) and the thickness of the soil layer. The $\mathrm{CO}_{2}$ equivalent of soil C sequestration rate (kg $\mathrm{CO}_{2} \mathrm{ha}^{-1} \cdot \mathrm{yr}^{-1}$ ) at $0-10 \mathrm{~cm}$ for each treatment was determined from the slope of linear regression equation of SOC content over time from 2006 to 2011 and multiplied by a factor of $3.67\left(\mathrm{CO}_{2} / \mathrm{C}\right)$. Although soil samples were collected from the $0-120 \mathrm{~cm}$ depth, results showed that $C$ sequestration from 2006 to 2011 occurred only at the $0-10 \mathrm{~cm}$ depth at both sites. Therefore, $\mathrm{C}$ sequestration rate for this study was considered only at this depth.

Crop yield was determined by harvesting malt barley and pea grains from the central rows of the plot (50 $\mathrm{m}^{2}$ area) using a combine harvester, oven drying a subsample at $60^{\circ} \mathrm{C}$ for $3 \mathrm{~d}$, and weighing. Annualized crop yield for a two-year crop rotation was calculated by averaging data from both phases within a rotation. Malt barley grain yield during the fallow phase in CTB-F/N1 and CTB-F/N0 was considered zero while calculating the annualized crop yield. In NTB-P/N1, annualized crop yield was calculated by averaging yields of malt barley and pea.

The GWP [2] [4] [8] was calculated as:

$\mathrm{GWP}=\mathrm{CO}_{2}$ equivalents (farm operations $+\mathrm{N}$ fertilization $+\mathrm{N}_{2} \mathrm{O}$ flux $+\mathrm{CH}_{4}$ flux) $-\mathrm{CO}_{2}$ equivalent (soil C sequestration rate).

The GHGI [3] was calculated as:

GHGI = GWP/annualized crop yield.

A system becomes a source of net GWP and GHGI if the values are positive and sink if they are negative [1] [3].

\subsection{Data Analysis}

Data for $\mathrm{CO}_{2}$ equivalents of $\mathrm{N}_{2} \mathrm{O}$ and $\mathrm{CH}_{4}$ fluxes and soil $\mathrm{C}$ sequestration rate, annualized crop yield, and net 
GWP and GHGI within a site were analyzed using the Analysis of Repeated Measures procedure in the SASMIXED model [25]. Treatment was considered as the fixed effect and year as the repeated measure variable for data analysis. Random variable was replication. For comparing sites, similar treatments (NTB-P/N1, NTB/N1, and NTB/N0) at both sites were also analyzed separately as above using site as a fixed effect. Since each phase of the crop rotation was present in every year, data were averaged across phases within a rotation and the average value was used for the analysis. When the treatment was significant, orthogonal contrast was used to determine the effect of individual treatments on measured parameters. Means were separated by using the least square means test when treatments and interactions were significant [25]. Statistical significance was evaluated at $P \leq 0.05$, unless otherwise stated.

\section{Results and Discussion}

\subsection{Nitrogen Fertilization}

Because of the variations in the amount of $\mathrm{N}$ fertilizer applied to malt barley in each treatment and year, $\mathrm{CO}_{2}$ equivalent of $\mathrm{N}$ fertilization also varied (Table 1 ). While no $\mathrm{N}$ fertilizer was applied to treatments containing $\mathrm{N} 0$, $\mathrm{CO}_{2}$ equivalents in other treatments were based on $\mathrm{N}$ fertilization rates. The values included $\mathrm{CO}_{2}$ equivalents from $\mathrm{N}$ fertilizer production, transportation, and application as direct emissions [10] and $\mathrm{NH}_{4}$ volatilization, $\mathrm{N}$ leaching, and urea hydrolysis as indirect emissions [22]. The $\mathrm{CO}_{2}$ equivalent was similar in $\mathrm{CTB} / \mathrm{N} 1$ and NTB/N1 in all years in Nesson Valley, North Dakota, but varied among treatments and years in Sidney, Montana. The $\mathrm{CO}_{2}$ equivalent was, however, lower in NTB-P/N1 than NTB/N1 at both sites due to N contribution from pea. Absence of $\mathrm{N}$ fertilization due to the presence of greater soil residual $\mathrm{NO}_{3}-\mathrm{N}$ level in the previous year resulted in non- $\mathrm{CO}_{2}$ contribution from CTB-F/N1 and NTB-P/N1 in 2008 in Sidney.

\subsection{Farm Operations}

The $\mathrm{CO}_{2}$ equivalents of fuel used in machinery equipments for farm operations (e.g. chisel tillage, crop planting, $\mathrm{P}$ and $\mathrm{K}$ fertilizer production and application, herbicide and pesticide production and application, harvest, and farm machinery production) were greater in till than no-till treatments in both Nesson Valley and Sidney (Table 2). Except tillage, same machinery equipments were used for other operations in all treatments. As a result, $\mathrm{CO}_{2}$ equivalents in other operations were similar. Production of $\mathrm{P}$ and $\mathrm{K}$ fertilizers emitted higher $\mathrm{CO}_{2}$ than the other farm operations, except tillage. Because $\mathrm{P}$ and $\mathrm{K}$ fertilizers were banded at the same rates and time to all treatments at planting, $\mathrm{CO}_{2}$ emissions from the application of these fertilizers and from planting were included as one operation.

\subsection{Soil Carbon Sequestration}

Soil C sequestration rate at $0-10 \mathrm{~cm}$ from 2006 to 2011 was greater in NTB-P/N1 than the other treatments, except NTB/N1 in Nesson Valley (Figure 2). Carbon was lost in CTB/N1, CTB/N0, and NTB/N0, with greater loss in CTB/N1 and CTB/N0 than NTB/N0. In Sidney, C sequestration rate was also greater in NTB-P/N1 and NTB/N1 than the other treatments and greater in CTB-F/N1 than CTB-F/N0 and NTB/N0. Averaged across NTB-P/N1, NTB/N1, and NTB/N0, C sequestration rate was greater in Sidney than in Nesson Valley, especially with the first two treatments.

The greater C sequestration rates in NTB-P/N1 and NTB/N1 both at Nesson Valley and Sidney were due to reduced soil disturbance as a result of absence of tillage, followed by increased amount of crop residue returned to the soil from continuous cropping and $\mathrm{N}$ fertilization. Halvorson et al. [26] reported that no-till continuous cropping increased dryland soil C sequestration at $0-15 \mathrm{~cm}$ by $854 \mathrm{~kg} \mathrm{CO}_{2}-\mathrm{C} \mathrm{ha}{ }^{-1} \cdot \mathrm{yr}^{-1}$ compared to a loss of $567 \mathrm{~kg} \mathrm{CO}_{2}-\mathrm{C} \mathrm{ha}^{-1} \cdot \mathrm{yr}^{-1}$ in conventional till crop-fallow in North Dakota, USA. Our values of $\mathrm{C}$ sequestration rates for dryland cropping systems were within the range reported by Halvorson et al. [26]. Nitrogen fertilization has been known to increase soil $\mathrm{C}$ sequestration compared with no $\mathrm{N}$ fertilization [27]. Increased $\mathrm{C}$ mineralization due to soil disturbance as a result of tillage, followed by reduced or absence of crop residue returned to the soil due to no $\mathrm{N}$ fertilization or fallow were probably the reasons for negative $\mathrm{C}$ sequestration rates in $\mathrm{CTB} / \mathrm{N} 1$, CTB/N0, NTB/N0, and CTB-F/N0 [11] [27]. Increased C mineralization due to higher precipitation and coarser soil texture also were the possible reasons for lower $\mathrm{C}$ sequestration rates in Nesson Valley than Sidney, since increased $\mathrm{CO}_{2}$ emissions in the former than the latter site have been known [17] [20]. 


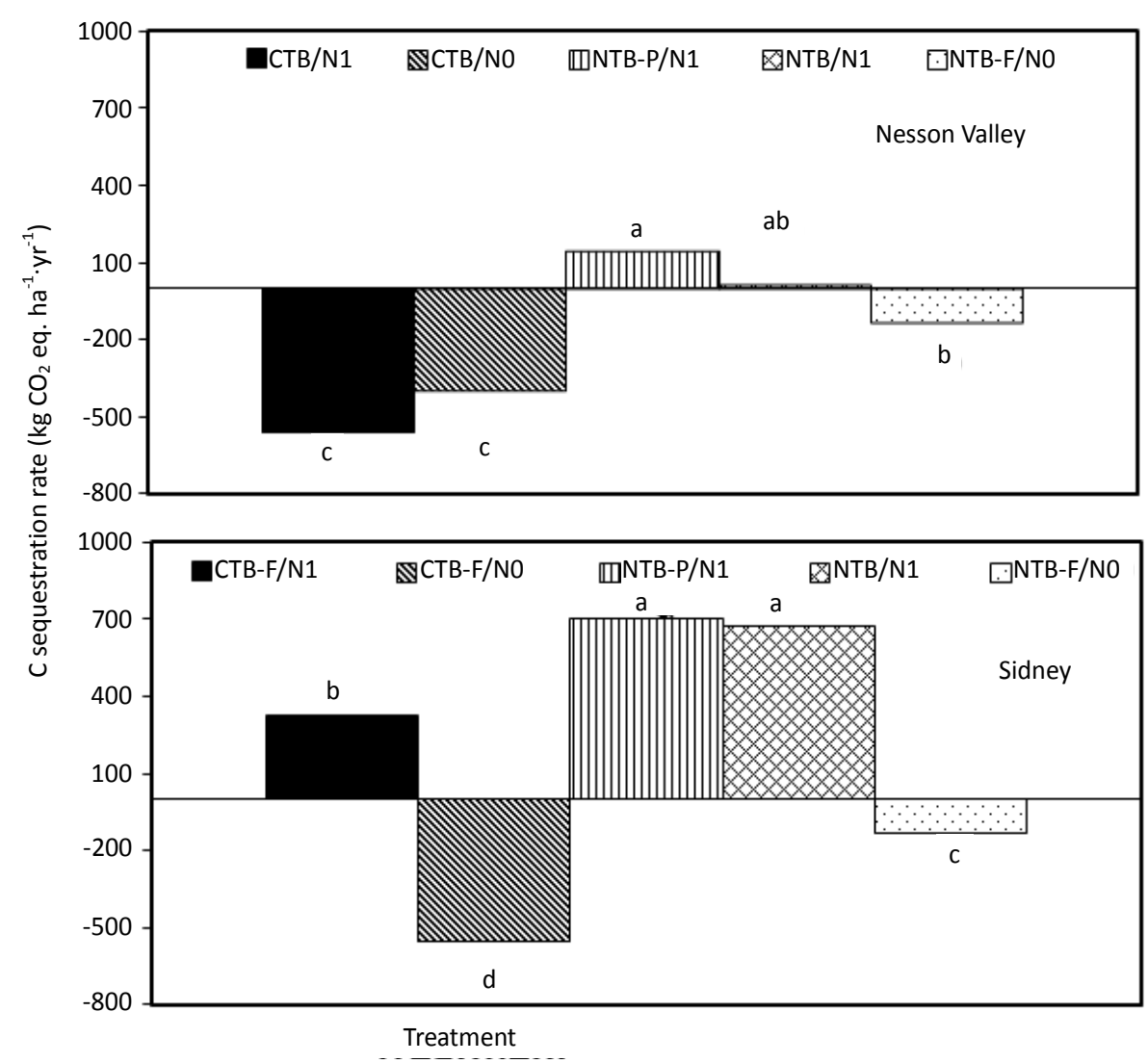

Figure 2. Soil C sequestration rates at the $0-10 \mathrm{~cm}$ depth from 2006 to 2011 as affected by management practices in Nesson Valley, North Dakota and Sidney, Montana. Management practices in Nesson Valley are CTB/N1, conventional till malt barley with $67 \mathrm{~kg} \mathrm{~N} \mathrm{ha}^{-1}$; $\mathrm{CTB} / \mathrm{N} 0$, conventional till malt barley with $0 \mathrm{~kg} \mathrm{~N}^{-1}$; NTB-P/N1, no-till malt barley-pea with $67 \mathrm{~kg} \mathrm{~N} \mathrm{ha}^{-1}$; NTB/N1, no-till malt barley with $67 \mathrm{~kg} \mathrm{~N}$ ha $^{-1}$; and NTB/N0, no-till malt barley with $0 \mathrm{~kg} \mathrm{~N} \mathrm{ha}^{-1}$. In Sidney, management practices are CTB-F/N1, conventional till malt barley-fallow with $80 \mathrm{~kg} \mathrm{~N} \mathrm{ha}^{-1}$; CTB-F/N0, conventional till malt barley-fallow with 0 $\mathrm{kg} \mathrm{N} \mathrm{ha}^{-1}$; NTB-P/N1, no-till malt barley-pea with $80 \mathrm{~kg} \mathrm{~N} \mathrm{ha}^{-1}$; NTB/N1, no-till malt barley with $80 \mathrm{~kg} \mathrm{~N}^{-1}$; and NTB/N0, no-till malt barley with $0 \mathrm{~kg} \mathrm{~N} \mathrm{ha}^{-1}$. Bars followed by different letters at the top and bottom are significantly different among management practices at $P=0.05$ by the least significance difference test.

\subsection{Nitrous Oxide and Methane Fluxes}

Nitrous oxide fluxes varied among treatments and years in both Nesson Valley and Sidney, a result of variations in soil temperature, water content, and management practices (Figure 3). In Nesson Valley, there was no difference in $\mathrm{N}_{2} \mathrm{O}$ flux among treatments in 2008, but the flux was usually greater in CTB/N1 and NTB/N1 and lower in NTB-P/N1 than the other treatments from 2009 to 2011. In Sidney, there was similarly no difference in $\mathrm{N}_{2} \mathrm{O}$ flux among treatments in 2009 and 2010, but the flux was greater in NTB-P/N1and NTB/N0 than CTB-F/ N0 in 2008 and greater in CTB-F/N0 and NTB-P/N1 than the other treatments in 2011. Mean $\mathrm{N}_{2} \mathrm{O}$ flux across years was lower in NTB-P/N1 than CTB/N1 and NTB/N1 in Nesson Valley. In Sidney, mean $\mathrm{N}_{2} \mathrm{O}$ flux was greater in NTB-P/N1 than NTB/N0. While N fertilization appeared to increase $\mathrm{N}_{2} \mathrm{O}$ flux in treatments with $\mathrm{N}$ compared with no $\mathrm{N}$ in Nesson Valley [3] [12] [13], tillage and fallow also promoted the flux in CTB-F/N0 during above-average precipitation in 2011 in Sidney, probably a result of higher soil $\mathrm{NO}_{3}-\mathrm{N}$ level due to increased organic N mineralization. Reverse trends in $\mathrm{N}_{2} \mathrm{O}$ flux in NTB-P/N1 than the other treatments in Nesson Valley and Sidney was surprising, but could be a result of differences in the rate of $\mathrm{N}$ fertilization and soil and climatic conditions. The $\mathrm{CO}_{2}$ equivalent of total $\mathrm{N}$ fertilization rate in NTB-P/N1 from 2008 to 2011 was $99 \mathrm{~kg} \cdot \mathrm{ha}^{-1}$ less in Nesson Valley than in Sidney (Table 1). 


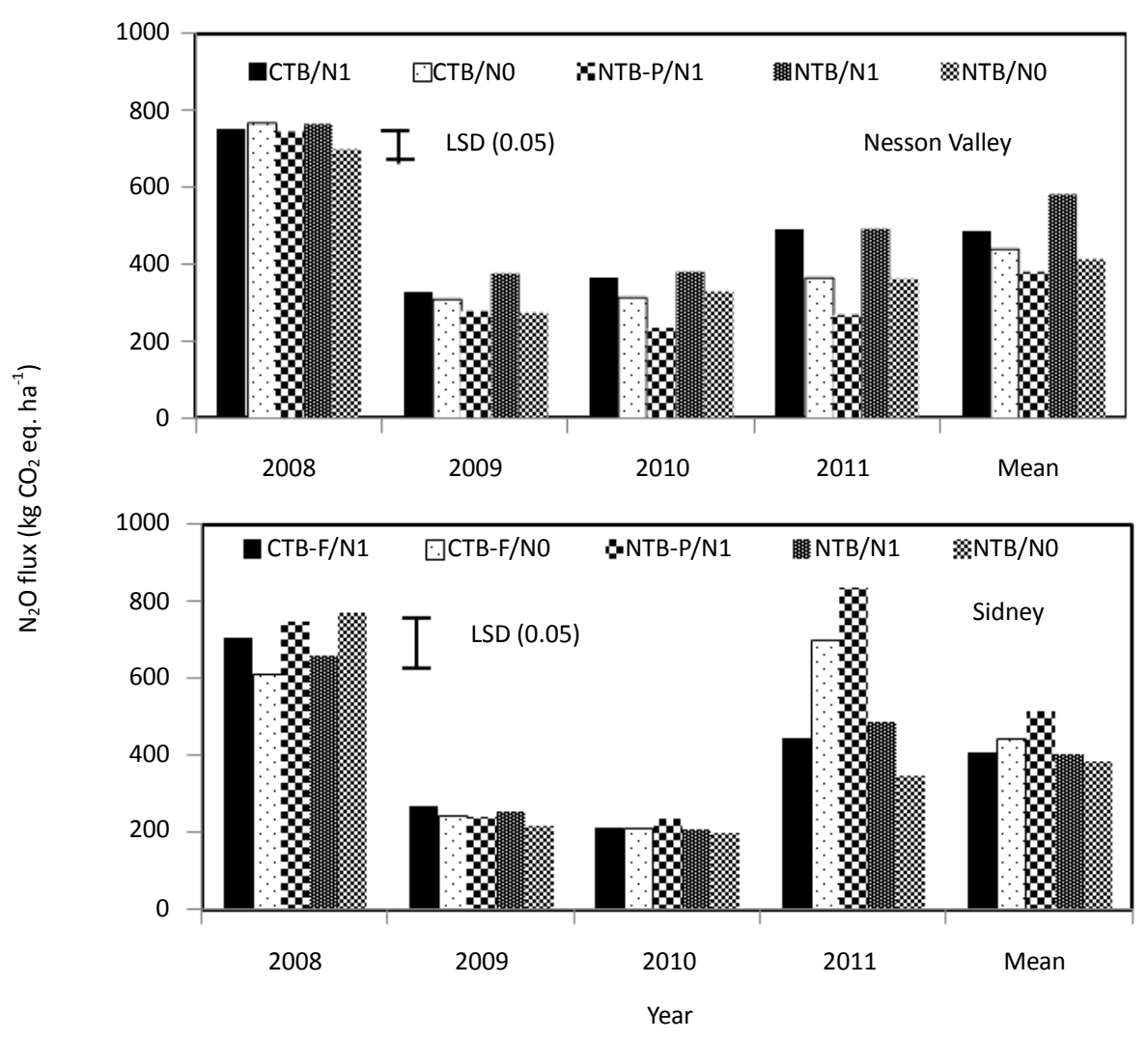

Figure 3. Soil surface $\mathrm{N}_{2} \mathrm{O}$ flux from 2008 to 2011 as affected by management practices in Nesson Valley, North Dakota and Sidney, Montana. Management practices in Nesson Valley are CTB/N1, conventional till malt barley with $67 \mathrm{~kg} \mathrm{~N}^{-1}$; CTB/N0, conventional till malt barley with $0 \mathrm{~kg} \mathrm{~N}^{-1}$; NTB-P/N1, no-till malt barley-pea with $67 \mathrm{~kg} \mathrm{~N} \mathrm{ha}^{-1}$; NTB/N1, no-till malt barley with $67 \mathrm{~kg} \mathrm{~N}^{-1}$; and NTB/N0, no-till malt barley with $0 \mathrm{~kg} \mathrm{~N} \mathrm{ha}^{-1}$. In Sidney, management practices are CTB-F/N1, conventional till malt barley-fallow with $80 \mathrm{~kg}$ $\mathrm{N} \mathrm{ha}^{-1}$; CTB-F/N0, conventional till malt barley-fallow with $0 \mathrm{~kg} \mathrm{~N} \mathrm{ha}^{-1}$; NTB-P/N1, no-till malt barley-pea with $80 \mathrm{~kg} \mathrm{~N}^{-1}$; $\mathrm{NTB} / \mathrm{N} 1$, no-till malt barley with $80 \mathrm{~kg} \mathrm{~N}^{-1}$; and NTB/N0, no-till malt barley with $0 \mathrm{~kg} \mathrm{~N}^{-1}$. LSD (0.05) is the least significant difference among management practices at $P=0.05$.

In contrast to $\mathrm{N}_{2} \mathrm{O}$ flux, $\mathrm{CH}_{4}$ flux was mostly negative in all treatments (Figure 4) and contributed a small portion of overall GWP. Dryland soils are typically a sink of $\mathrm{CH}_{4}$ due to its consumption by methanotrophs [28] and $\mathrm{CH}_{4}$ uptake can be higher as soils become more drier [4]. As with $\mathrm{N}_{2} \mathrm{O}$ flux, $\mathrm{CH}_{4}$ flux also varied with treatments and years at both Nesson Valley and Sidney. In Nesson Valley, $\mathrm{CH}_{4}$ uptake was greater in $\mathrm{CTB} / \mathrm{N} 1$, CTB/N0, and NTB-P/N1 than NTB/N1 in 2008 and 2010 and greater in NTB-P/N1 and NTB/N1 than NTB/NO in 2009. In Sidney, $\mathrm{CH}_{4}$ uptake was greater in NTB/N1 than most other treatments in all years, except in 2008 when the flux was greater in CTB-F/N0. While mean $\mathrm{CH}_{4}$ uptake across years was not different among treatments in Nesson Valley, the uptake was greater in NTB/N1 than the other treatments, except CTB-F/N0, in Sidney whose reasons were not known.

\subsection{Global Warming Potential}

Net GWP was greater in CTB/N1 and lower in NTB-P/N1 than most other treatments in all years in Nesson Valley (Figure 5). In Sidney, GWP was greater in CTB-F/N0, but lower in NTB-P/N1 and NTB/N1 than the other treatments in all years, except in 2011 when GWP was lower in NTB/N1. Mean GWP across years and similar treatments (NTB-P/N1, NTB/N1, and NTB/N0) was 56\% greater in Nesson Valley than Sidney.

The greater GWP in CTB/N1 than the other treatments in Nesson Valley was due to increased $\mathrm{CO}_{2}$ contributions from $\mathrm{N}$ fertilization (Table 1), farm operations (Table 2), and $\mathrm{N}_{2} \mathrm{O}$ emissions (Figure 3), followed by a 


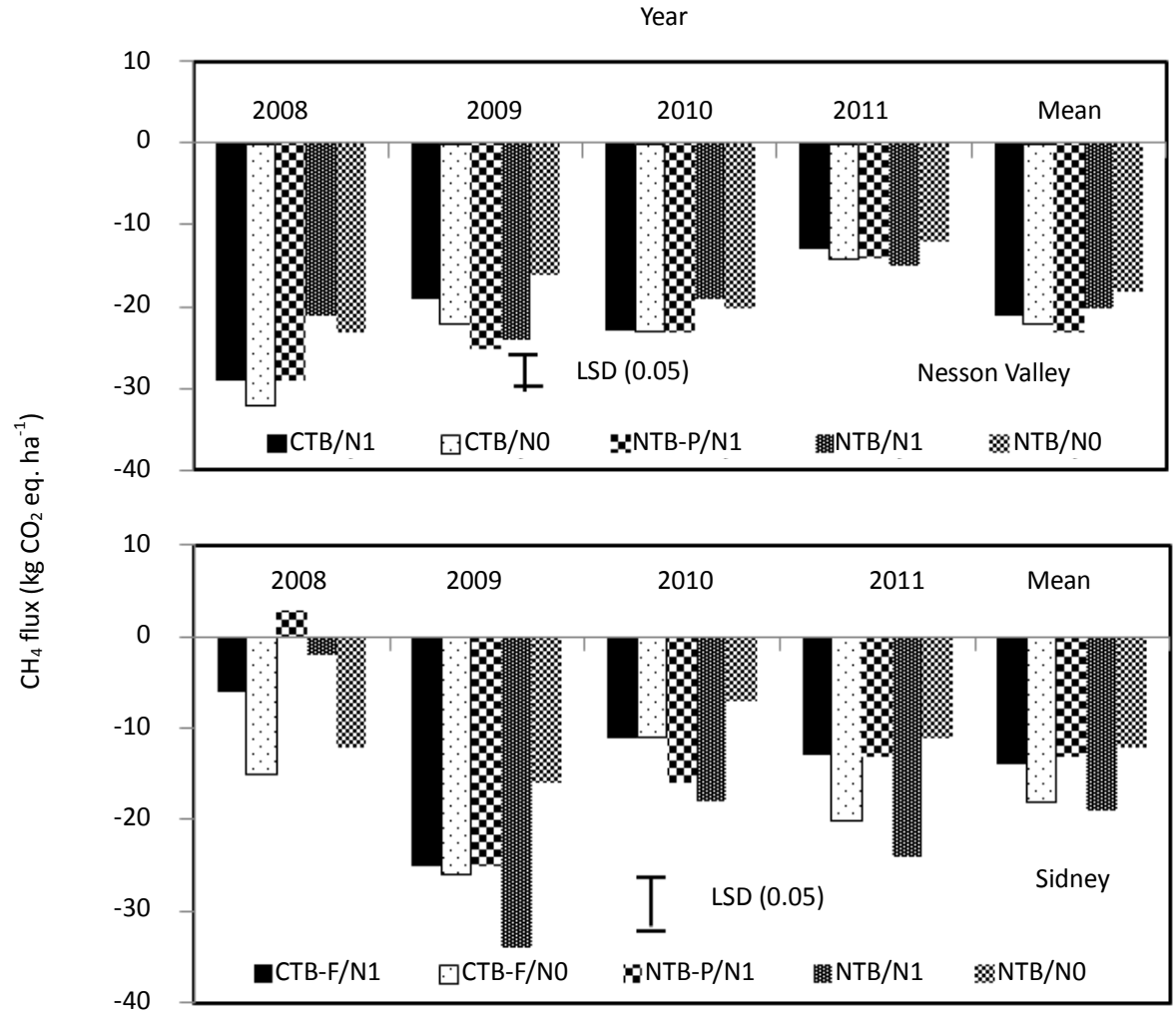

Figure 4. Soil surface $\mathrm{CH}_{4}$ flux from 2008 to 2011 as affected by management practices in Nesson Valley, North Dakota and Sidney, Montana. Management practices in Nesson Valley are CTB/N1, conventional till malt barley with $67 \mathrm{~kg} \mathrm{~N}^{-1}$; CTB/N0, conventional till malt barley with $0 \mathrm{~kg} \mathrm{~N}^{-1}{ }^{-1}$; NTB-P/N1, no-till malt barley-pea with $67 \mathrm{~kg} \mathrm{~N} \mathrm{ha}^{-1}$; NTB/N1, no-till malt barley with $67 \mathrm{~kg} \mathrm{~N}^{-1}$; and NTB/N0, no-till malt barley with $0 \mathrm{~kg} \mathrm{~N} \mathrm{ha}^{-1}$. In Sidney, management practices are CTB-F/N1, conventional till malt barley-fallow with $80 \mathrm{~kg}$ $\mathrm{N} \mathrm{ha}^{-1}$; CTB-F/N0, conventional till malt barley-fallow with $0 \mathrm{~kg} \mathrm{~N}^{-1}$; $\mathrm{NTB}-\mathrm{P} / \mathrm{N} 1$, no-till malt barley-pea with $80 \mathrm{~kg} \mathrm{~N} \mathrm{ha}^{-1}$; NTB/N1, no-till malt barley with $80 \mathrm{~kg} \mathrm{~N} \mathrm{ha}^{-1}$; and NTB/N0, no-till malt barley with $0 \mathrm{~kg} \mathrm{~N} \mathrm{ha}^{-1}$. LSD (0.05) is the least significant difference among management practices at $P=0.05$.

lower $\mathrm{C}$ sequestration rate (Figure 2). This suggests that both tillage and $\mathrm{N}$ fertilization can increase GWP compared with no-tillage and $\mathrm{N}$ fertilization. This was also confirmed by greater average GWP of CTB/N1 and $\mathrm{CTB} / \mathrm{N} 0$ than NTB/N1 and NTB/N0 (tillage effect) or greater average GWP of CTB/N1 and NTB/N1 than CTB/N0 and NTB/N0 (N fertilization effect). Several researchers [2] [8] [29] have also reported greater GWP with tillage and $\mathrm{N}$ fertilization than without. Similarly, lower GWP in NTB-P/N1 than NTB/N1 suggests that legume-nonlegume crop rotation can reduce GWP compared with continuous nonlegume monocropping, a case similar to that reported by Lemke et al. [30].

Similar to Nesson Valley, greater GWP in CTB-F/N0 than the other treatments in Sidney was due to greater $\mathrm{CO}_{2}$ contributions from farm operations (Table 2) and $\mathrm{N}_{2} \mathrm{O}$ emissions (Figure 3), followed by a lower $\mathrm{C}$ sequestration rate (Figure 2). Although tillage increased GWP, fallowing may have a greater role in enhancing GWP in CTB-F/N0 due to the lower amount of crop residue returned to the soil as a result of the absence of crops during fallow and increased organic matter mineralization as a result of enhanced microbial activity from increased soil temperature and water content [25]. Increased GWP in crop-fallow compared with continuous cropping has been reported by several researchers [2] [30]. In contrast to Nesson Valley, lower GWP in CTB-F/N1 vs. CTB-F/N0 and NTB/N1 vs. NTB/N0 suggest that N fertilization actually reduced GWP compared with no $\mathrm{N}$ fertilization due to increased $\mathrm{C}$ sequestration rate (Figure 2). Mosier et al. [3] found that appropriate level of $\mathrm{N}$ fertilization, in fact, reduced GWP compared with no $\mathrm{N}$ fertilization because of increased $\mathrm{C}$ sequestration. 


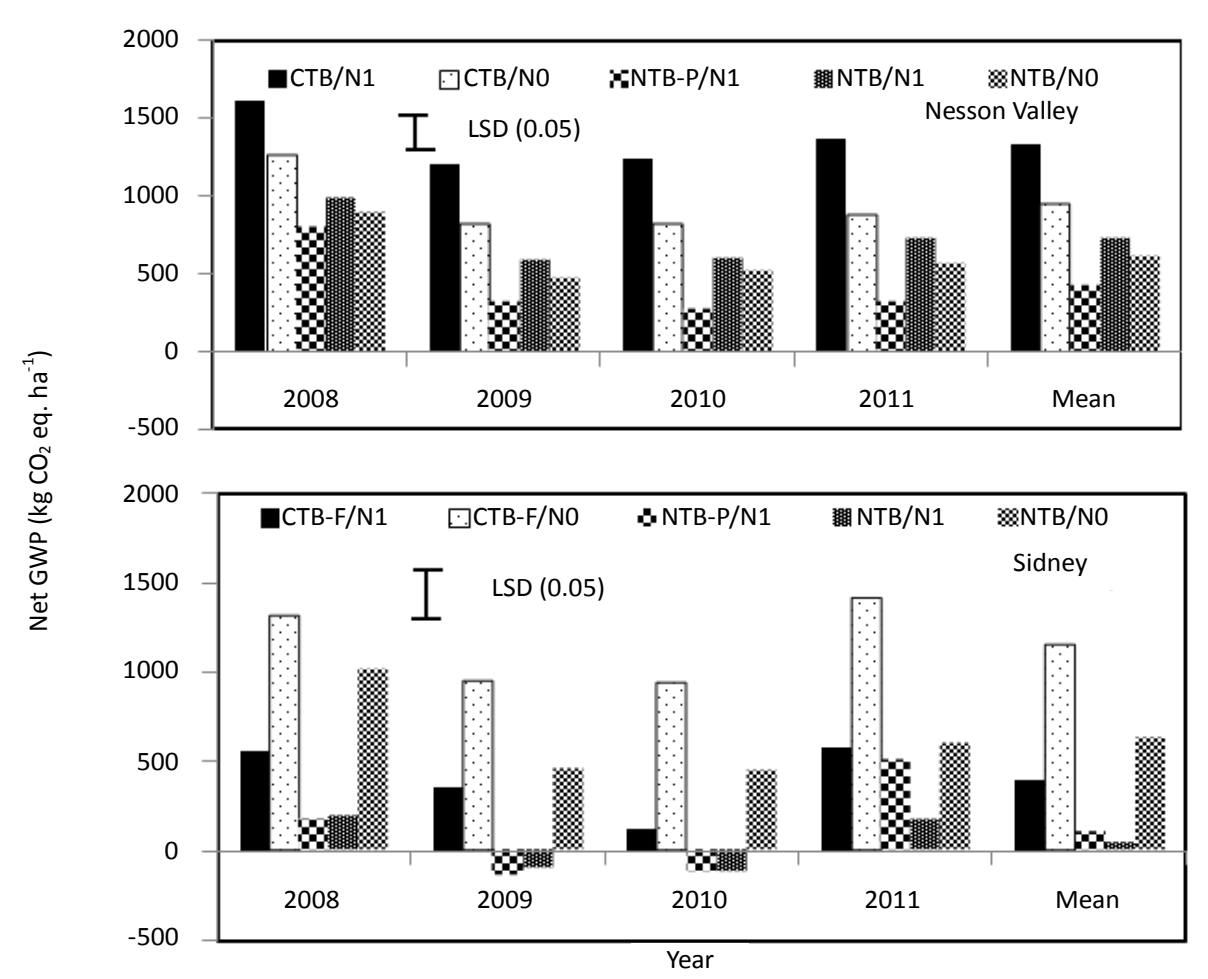

Figure 5. Net global warming potential (GWP) from 2008 to 2011 as affected by management practices in Nesson Valley, North Dakota and Sidney, Montana. Management practices in Nesson Valley are CTB/N1, conventional till malt barley with $67 \mathrm{~kg} \mathrm{~N} \mathrm{ha}^{-1}$; CTB/N0, conventional till malt barley with $0 \mathrm{~kg} \mathrm{~N}^{-1}$; NTB-P/N1, no-till malt barley-pea with $67 \mathrm{~kg}$ $\mathrm{N} \mathrm{ha}^{-1}$; NTB/N1, no-till malt barley with $67 \mathrm{~kg} \mathrm{~N}^{-1} \mathrm{a}^{-1}$; and NTB/N0, no-till malt barley with $0 \mathrm{~kg} \mathrm{~N}$ ha $^{-1}$. In Sidney, management practices are CTB-F/N1, conventional till malt barley-fallow with $80 \mathrm{~kg} \mathrm{~N}^{-1}$; CTB-F/N0, conventional till malt barley-fallow with $0 \mathrm{~kg} \mathrm{~N}$ ha $^{-1}$; NTB-P/N1, no-till malt barley-pea with $80 \mathrm{~kg} \mathrm{~N}^{-1}{ }^{-1}$; NTB/N1, no-till malt barley with $80 \mathrm{~kg} \mathrm{~N} \mathrm{ha}^{-1}$; and NTB/N0, no-till malt barley with $0 \mathrm{~kg} \mathrm{~N}^{-1}$. LSD (0.05) is the least significant difference among management practices at $P=0.05$.

Greater GWP across similar treatments in Nesson Valley than Sidney was due to higher $\mathrm{N}_{2} \mathrm{O}$ flux and lower C sequestration rate (Figure 2 and Figure 3). Slightly higher precipitation (373 vs. $350 \mathrm{~mm}$ ) and coarser soil texture may have increased organic matter mineralization, resulting in enhanced GWP in Nesson Valley. Greater $\mathrm{CO}_{2}$ emissions and lower SOC storage in Nesson Valley than Sidney have been previously reported [17] [20].

\subsection{Annualized Crop Yield}

Annualized crop grain yield was lower in CTB/N0 and NTB/N0 than the other treatments in all years, except in 2008 when yield in CTB/N0 was not different from CTB/N1 and NTB-P/N1 in Nesson Valley (Figure 6). Mean yield across years was lower in CTB/N0 and NTB/N0 than the other treatments, suggesting that the absence of $\mathrm{N}$ fertilization reduced crop yield. In Sidney, crop yield varied among treatments and years. In 2008 when annual precipitation was below the average, yield was greater in CTB-F/N1 and CTB-F/N0 than the other treatments due to increased soil water conservation during fallow. In other years with normal or above-average precipitation, yield was greater in NTB-P/N1 and NTB/N1 than the other treatments, possibly a result of increased soil water conservation due to the absence of tillage, followed by $\mathrm{N}$ fertilization. Comparison of crop yields across years and similar treatments indicated that yield was 29\% greater in Nesson Valley than in Sidney, possibly a result of greater soil water and nutrient availability from increased organic matter mineralization.

\subsection{Greenhouse Gas Intensity}

Net GHGI was greater in CTB/NO than the other treatments in 2009 and 2011 in Nesson Valley (Figure 7). In 


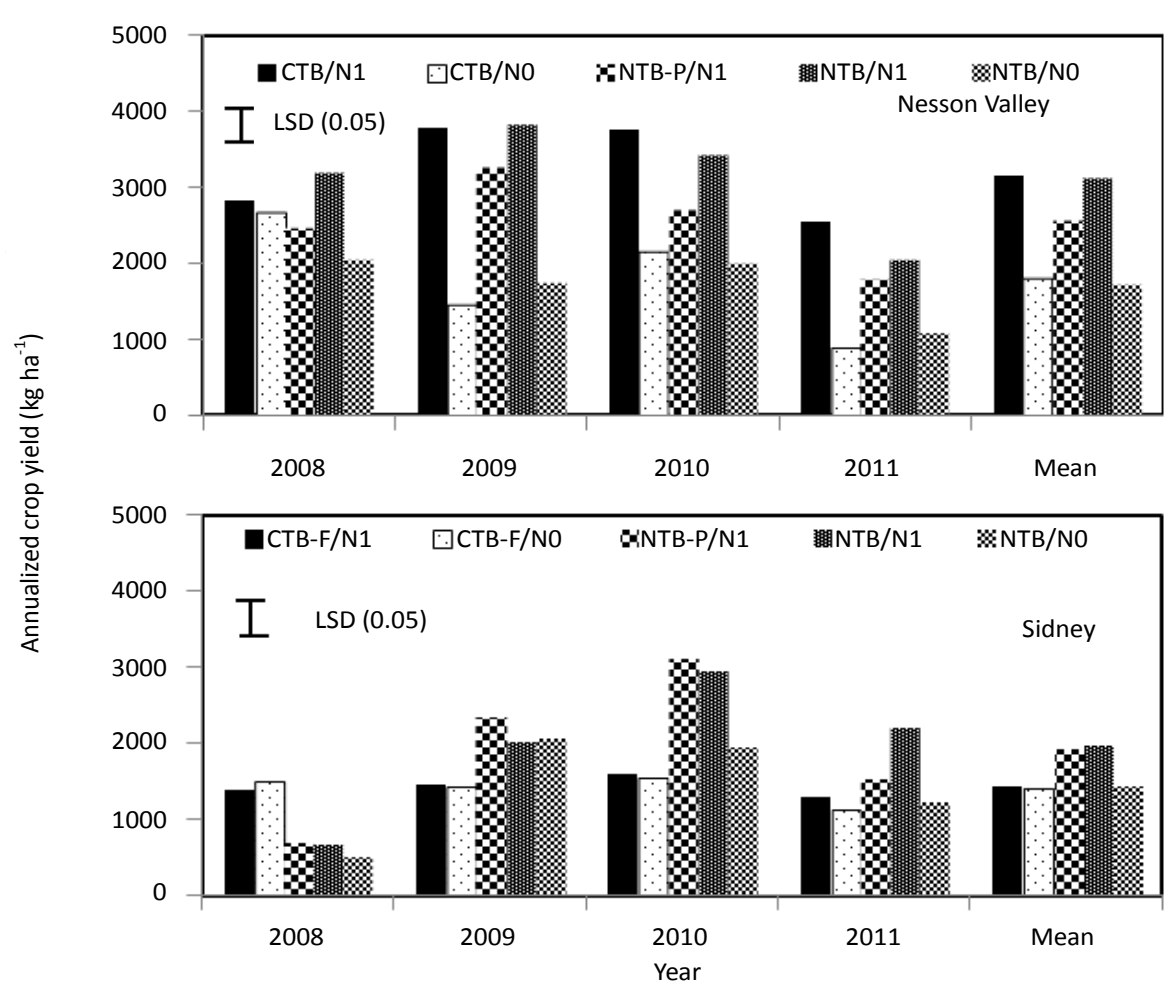

Figure 6. Annualized crop grain yield from 2008 to 2011 as affected by management practices in Nesson Valley, North Dakota and Sidney, Montana. Management practices in Nesson Valley are CTB/N1, conventional till malt barley with $67 \mathrm{~kg} \mathrm{~N} \mathrm{ha}^{-1}$; CTB/N0, conventional till malt barley with $0 \mathrm{~kg} \mathrm{~N}^{-1}$; NTB-P/N1, no-till malt barley-pea with $67 \mathrm{~kg} \mathrm{~N}^{-1}$; NTB/N1, no-till malt barley with $67 \mathrm{~kg} \mathrm{~N} \mathrm{ha}^{-1}$; and NTB/N0, no-till malt barley with $0 \mathrm{~kg} \mathrm{~N}$ $\mathrm{ha}^{-1}$. In Sidney, management practices are CTB-F/N1, conventional till malt barley-fallow with $80 \mathrm{~kg} \mathrm{~N} \mathrm{ha}^{-1}$; CTB-F/N0, conventional till malt barley-fallow with $0 \mathrm{~kg} \mathrm{~N}^{-1}$; NTB-P/ $\mathrm{N} 1$, no-till malt barley-pea with $80 \mathrm{~kg} \mathrm{~N} \mathrm{ha}^{-1}$; NTB/N1, no-till malt barley with $80 \mathrm{~kg} \mathrm{~N}^{-1}$; and NTB/N0, no-till malt barley with $0 \mathrm{~kg} \mathrm{~N} \mathrm{ha}^{-1}$. LSD (0.05) is the least significant difference among management practices at $P=0.05$.

2008, GHGI was greater in CTB/N1 than NTB-P/N1 and NTB/N1. In 2010, GHGI was greater in CTB/N0 than the other treatments, except CTB/N1. Mean GHGI across years was greater in CTB/N0 than the other treatments. In Sidney, GHGI was greater in NTB/N0 than the other treatments in 2008. From 2009 to 2011, GHGI was greater in CTB-F/N0 than the other treatments. Mean GHGI across years and similar treatments was 36\% greater in Nesson Valley than Sidney.

Increased GWP (Figure 5), followed by reduced crop yield (Figure 6) increased GHGI in CTB/N0 in Nesson Valley. As with GWP, greater mean GHGI of CTB/N1 and CTB/N0 than NTB/N1 and NTB/N0 indicated that tillage increased GHGI compared with no-tillage. In contrast, $\mathrm{N}$ fertilization reduced GHGI compared with no $\mathrm{N}$ fertilization, as evidenced by lower average GHGI of CTB/N1 and NTB/N1 than CTB/N0 and NTB/N0. Increased GHGI with tillage than without was similar to those reported by several researchers [3] [31], but $\mathrm{N}$ fertilization had a variable effect on GHGI [3] [29] [32]. Similar GHGI in NTB-P/N1 and NTB/N1 suggest that crop rotation had no effect on GHGI. While GHGI not affected by crop rotation [30], it was greater in corn (Zea mays L.)-soybean (Glycine max L.) rotation than continuous corn [3] [33].

As with Nesson Valley, increased GWP (Figure 5), followed by reduced crop yield (Figure 6) increased GHGI in CTB-F/N0 in Sidney. Tillage, fallow, and absence of $\mathrm{N}$ fertilization probably increased GHGI in this treatment, a case similar to that observed for GWP. Lower mean GHGI in CTB-F/N1 and NTB/N1 than CTB-F/N0 and NTB-F/N0 shows that N fertilization reduced GHGI compared with no $\mathrm{N}$ fertilization by increasing crop yield, a case similar to that observed in Nesson Valley. Similarly, non-differences in GHGI between NTB-P/N1 and NTB/NI suggest that crop rotation has little effect on GHGI. Increased GHGI across years and similar treatments in Nesson Valley compared with Sidney was similar to that observed for GWP. 


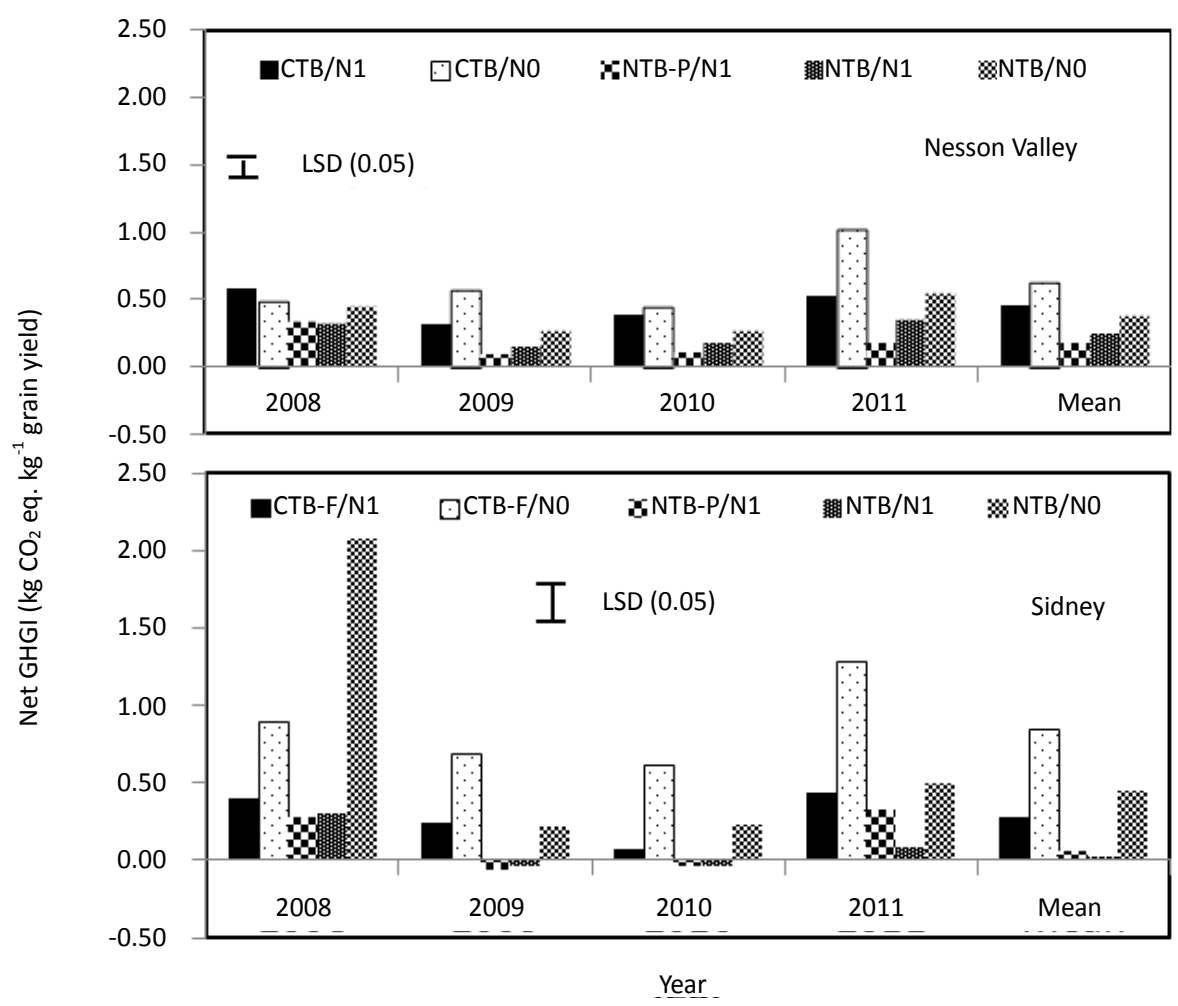

Figure 7. Net greenhouse gas intensity (GHGI) from 2008 to 2011 as affected by management practices in Nesson Valley, North Dakota and Sidney, Montana. Management practices in Nesson Valley are CTB/N1, conventional till malt barley with $67 \mathrm{~kg} \mathrm{~N} \mathrm{ha}^{-1}$; CTB/N0, conventional till malt barley with $0 \mathrm{~kg} \mathrm{~N} \mathrm{ha}^{-1}$; NTB-P/N1, no-till malt barley-pea with $67 \mathrm{~kg}$ $\mathrm{N} \mathrm{ha}^{-1}$; NTB/N1, no-till malt barley with $67 \mathrm{~kg} \mathrm{~N} \mathrm{ha}^{-1}$; and NTB/N0, no-till malt barley with $0 \mathrm{~kg} \mathrm{~N} \mathrm{ha}{ }^{-1}$. In Sidney, management practices are CTB-F/N1, conventional till malt barley-fallow with $80 \mathrm{~kg} \mathrm{~N}^{-1}$; CTB-F/N0, conventional till malt barley-fallow with $0 \mathrm{~kg} \mathrm{~N}$ ha $^{-1}$; NTB-P/N1, no-till malt barley-pea with $80 \mathrm{~kg} \mathrm{~N}^{-1}{ }^{-1}$;TB/N1, no-till malt barley with $80 \mathrm{~kg} \mathrm{~N} \mathrm{ha}^{-1}$; and NTB/N0, no-till malt barley with $0 \mathrm{~kg} \mathrm{~N} \mathrm{ha}^{-1}$. LSD (0.05) is the least significant difference among management practices at $P=0.05$.

\subsection{Management Practice Implication}

Similar or lower net GWP and GHGI in NTB-P/N1 and NTB/N1 than the other treatments in Nesson Valley and Sidney (Figure 5 and Figure 7) demonstrated that no-till continuous cropping with adequate $\mathrm{N}$ fertilization can reduce net GHG emissions per unit area or unit grain yield compared with the traditional systems under dryland cropping systems in the semiarid regions. One advantage with legume-nonlegume crop rotation compared with continuous nonlegume monocropping is that legume-nonlegume rotation reduced $\mathrm{N}$ fertilization rate (Table 1) by supplying additional $\mathrm{N}$ from legume residue. Legume-nonlegume rotation has fewer weed, disease, and pest problems than continuous nonlegumes [34]. Carbon sequestration rate and crop yield were also similar between NTB-P/N1 and NTB/N1 (Figure 2 and Figure 6). These results suggest that no-till with legume-nonlegume crop rotation with adequate rate of $\mathrm{N}$ fertilization can be recommended as a robust management option to mitigate net GHG emissions, improve soil quality, reduce chemical inputs, and sustain crop yields compared with the traditional systems under dryland cropping systems, regardless of soil and climatic conditions. The results can be applied to other dryland farming regions engaged in small grain productions with similar soil and climatic conditions.

\section{Conclusion}

Differences in $\mathrm{CO}_{2}$ contributions from farm operations, $\mathrm{N}$ fertilization rates, $\mathrm{N}_{2} \mathrm{O}$ and $\mathrm{CH}_{4}$ fluxes, and soil C sequestration rates as well as soil and climatic conditions resulted in variations in net GWP and GHGI among 
treatments and study sites. Increased $\mathrm{CO}_{2}$ contributions from farm operations and $\mathrm{N}$ fertilization and reduced $\mathrm{C}$ sequestration rate increased GWP in CTB/N1 compared with the other treatments in Nesson Valley, North Dakota. Similarly, increased $\mathrm{CO}_{2}$ contributions from farm operations and $\mathrm{N}_{2} \mathrm{O}$ flux and reduced $\mathrm{C}$ sequestration rate increased GWP in CTB-F/N0 compared with the other treatments in Sidney, Montana. Compared with the other treatments, increased GWP, followed by lower crop yield increased GHGI in CTB/N0 in Nesson Valley and CTB-F/NO in Sidney. In contrast, lower $\mathrm{CO}_{2}$ contributions from farm operations and $\mathrm{N}_{2} \mathrm{O}$ flux and higher $\mathrm{C}$ sequestration rate reduced GWP and GHGI in NTB-P/N1 and NTB/N1 in both Nesson Valley and Sidney. Comparison of similar treatments between sites showed that GWP and GHGI were lower in Sidney with finer soil texture than Nesson Valley with coarser texture. These findings supported my hypothesis. Both GWP and GHGI were lower with tillage than without in Nesson Valley, but $\mathrm{N}$ fertilization had a variable effect in these parameters. Although GWP and GHGI were similar between NTB-P/N1 and NTB/N1, chemical inputs could be lower in NTB-P/N1 due to reduced N fertilization rate and herbicide and pesticide applications. As a result, no-till legume-nonlegume crop rotation with adequate $\mathrm{N}$ fertilization can mitigate net GHG emissions, reduce chemical inputs, improve soil quality, and sustain dryland crop yields compared with the traditional systems in the semiarid regions engaged in small grain production, regardless of soil and climatic conditions. The results can be applied to other regions with similar soil and climatic conditions and cropping systems.

\section{Acknowledgements}

I acknowledge the excellent help and support provided Joy Barsotti, Jana Seright, Christopher Russell, Michael Johnson, Mark Gaffri, Bart Stevens, Bill Iversen, and Bryan Gebhard for management of field plots and collection and analysis of gas, soil, and plant samples in the laboratory.

\section{References}

[1] Robertson, G.P., Paul, E. and Harwood, R. (2000) Greenhouse Gases in Intensive Agriculture: Contribution of Individual Gases to the Radiative Forcing of the Atmosphere. Science, 289, 1922-1925. http://dx.doi.org/10.1126/science.289.5486.1922

[2] Mosier, A.R., Halvorson, A.D., Peterson, C.A., Robertson, G.P. and Sherrod, L. (2005) Measurement of Net Global Warming Potential in Three Agroecosystems. Nutrient Cyclingin Agroecosystems, 72, 67-76. http://dx.doi.org/10.1007/s10705-004-7356-0

[3] Mosier, A.R., Halvorson, A.D., Reule, C.A. and Liu, X.J. (2006) Net Global Warming Potential and Greenhouse Gas Intensity in Irrigated Cropping Systems in Northeastern Colorado. Journal of Environmental Quality, 35, 1584-1598. http://dx.doi.org/10.2134/jeq2005.0232

[4] Liebig, M.A., Tanaka, D.L. and Gross, J.R. (2010) Fallow Effects on Soil Carbon and Greenhouse Gas Flux in Central North Dakota. Soil Science Society of America Journal, 74, 358-365. http://dx.doi.org/10.2136/sssaj2008.0368

[5] Schlesinger, W.H. (1999) Carbon Sequestration in Soils. Science, 284, 2095-2097. http://dx.doi.org/10.1126/science.284.5423.2095

[6] West, T.O. and Marland, G. (2002) A Synthesis of Carbon Sequestration, Carbon Emissions, and Net Carbon Flux in Agriculture: Comparing Tillage Practices in the United States. Agriculture Ecosystem and Environment, 91, $217-232$. http://dx.doi.org/10.1016/S0167-8809(01)00233-X

[7] Paustian, K., Robertson, G.P. and Elliott, E.T. (1995) Management Impacts on Carbon Storage and Gas Fluxes in MidLatitudes Cropland. In: Lal, R., Ed., Soils and Global Climate Change, Advances in Soil Science, CRC Press, Boca Raton, 69-83.

[8] Robertson, G.P. and Grace, P.R. (2004) Greenhouse Gas Fluxes in Tropical and Temperate Agriculture: The Need for a Full-Cost Accounting of Global Warming Potentials. Environmental Development and Sustainability, 6, 51-63. http://dx.doi.org/10.1023/B:ENVI.0000003629.32997.9e

[9] Drury, C.F., Reynolds, W.D., Tan, C.S., Welacky, T.W., Calder, W. and McLaughlin, N.B. (2006) Emissions of Nitrous Oxide and Carbon Dioxide: Influence of Tillage Type and Nitrogen Placement Depth. Soil Science Society of America Journal, 70, 570-581. http://dx.doi.org/10.2136/sssaj2005.0042

[10] Follett, R.F. (2001) Soil Management Concepts and Carbon Sequestration in Cropland Soils. Soil and Tillage Research, 61, 77-92. http://dx.doi.org/10.1016/S0167-1987(01)00180-5

[11] Sainju, U.M., Jabro, J.D. and Caesar-TonThat, T. (2010) Tillage, Cropping Sequence, and Nitrogen Fertilization Effects on Dryland Soil Carbon Dioxide Emission and Carbon Content. Journal of Environmental Quality, 39, 935-945. http://dx.doi.org/10.2134/jeq2009.0223 
[12] Dusenbury, M.P., Engel, R.E., Miller, P.R., Lemke, R.L. and Wallander, R. (2008) Nitrous Oxide Emissions from a Northern Great Plains Soil as Influenced by Nitrogen Management and Cropping Systems. Journal of Environmental Quality, 37, 542-550. http://dx.doi.org/10.2134/jeq2006.0395

[13] Robertson, G.P. and Vitousek, P.M. (2009) Nitrogen in Agriculture: Balancing the Cost of an Essential Resource. Annual Review in Environmental Resources, 34, 97-125. http://dx.doi.org/10.1146/annurev.environ.032108.105046

[14] Bronson, K.F. and Mosier, A.R. (1994) Suppression of Methane Oxidation in Aerobic Soil by Nitrogen Fertilizers, Nitrification Inhibitors, and Urease Inhibitors. Biology and Fertility of Soils, 17, 263-268. http://dx.doi.org/10.1007/BF00383979

[15] Al-Kaisi, M.M., Kruse, M.L. and Sawyer, J.E. (2008) Effect of Nitrogen Fertilizer Application on Growing Season Carbon Dioxide Emissions in a Corn-Soybean Rotation. Journal of Environmental Quality, 37, 325-332. http://dx.doi.org/10.2134/jeq2007.0240

[16] Bauer, A. and Black, A.L. (1994) Quantification of the Effect of Soil Organic Matter Content on Soil Productivity. Soil Science Society of America Journal, 58, 185-193. http://dx.doi.org/10.2136/sssaj1994.03615995005800010027x

[17] Sainju, U.M., Jabro, J.D. and Stevens, W.B. (2008) Soil Carbon Dioxide Emission and Carbon Content as Affected by Irrigation, Tillage, Cropping System, and Nitrogen Fertilization. Journal of Environmental Quality, 37, 98-106. http://dx.doi.org/10.2134/jeq2006.0392

[18] McCarl, B.A. and Schneider, U.A. (2001) Greenhouse Gas Mitigation in US Agriculture and Forestry. Science, 294, 2481-2482. http://dx.doi.org/10.1126/science.1064193

[19] Council for Agricultural Science and Technology (2003) Agriculture’s Response to Global Climate Change. CAST, Ames.

[20] Sainju, U.M., Caesar-TonThat, T. and Caesar, A. (2012) Comparison of Soil Carbon Dioxide Flux Measurements by Static and Portable Chambers in Various Management Practices. Soil and Tillage Research, 118, 123-131. http://dx.doi.org/10.1016/j.still.2011.10.020

[21] Intergovernmental Panel on Climate Change, IPCC (2007) Climate Change 2007. The Physical Science Basis. 4th Assessment Report, IPCC Secretariat, Geneva.

[22] Crutzen, P.J., Mosier, A.R., Smith, K.A. and Winiwarter, W. (2008) $\mathrm{N}_{2} \mathrm{O}$ Release from Agro-Biofuel Production Negates Global Warming Reduction by Replacing Fossil Fuels. Atmospheric Chemistry and Physics, 8, 389-395. http://dx.doi.org/10.5194/acp-8-389-2008

[23] Lal, R. (2004) Carbon Emission from Farm Operations. Environmental International, 30, 981-990. http://dx.doi.org/10.1016/j.envint.2004.03.005

[24] Nelson, D.W. and Sommers, L.E. (1996) Total Carbon, Organic Carbon, and Organic Matter. In: Sparks, D.L., Ed., Methods of Soil Analysis, Part 3, Chemical Methods, Book Series 5, Soil Science Society of America, Madison, 9611010.

[25] Littell, R.C., Milliken, G.A., Stroup, W.W. and Wolfinger, R.D. (1996) SAS System for Mixed Models. SAS Institute Inc., Cary.

[26] Halvorson, A.D., Wienhold, B.J. and Black, A.L. (2002) Tillage, Nitrogen, and Cropping System Effects on Soil Carbon Sequestration. Soil Science Society of America Journal, 66, 906-912. http://dx.doi.org/10.2136/sssaj2002.9060

[27] Halvorson, A.D., Reule, C.A. and Follett, R.F. (1999) Nitrogen Fertilization Effects on Soil Carbon and Nitrogen in a Dryland Cropping System. Soil Science Society of America Journal, 63, 912-917. http://dx.doi.org/10.2136/sssaj1999.634912x

[28] Sylvia, D.M., Fuhrman, J.J., Hartel, P.G. and Zuberer, D.A. (1998) Principles and Applications of Soil Microbiology. Prentice Hall, Upper Saddle River.

[29] Archer, D.W. and Halvorson, A.D. (2010) Greenhouse Gas Mitigation Economics for Irrigated Cropping Systems in Northeastern Colorado. Soil Science Society of America Journal, 74, 446-452. http://dx.doi.org/10.2136/sssaj2009.0080

[30] Lemke, R.L., Zhong, Z., Campbell, C.A. and Zentner, R. (2007) Can Pulse Crops Play a Role in Mitigating Greenhouse Gases from North American Agriculture? Agronomy Journal, 99, 1719-1725. http://dx.doi.org/10.2134/agronj2006.0327s

[31] Barsotti, J.L., Sainju, U.M., Lenssen, A.W., Montagne, C. and Hatfield, P.G. (2013) Net Greenhouse Gas Emissions Affected by Sheep Grazing in Dryland Cropping Systems. Soil Science Society of America Journal, 77, 1012-1025. http://dx.doi.org/10.2136/sssaj2012.0386

[32] Pittelkow, C.M., Adviento-Borbe, M.A., Hill, J.E., Six, J., van Kissel, C. and Linquist, B.A. (2013) Yield-Scaled Global Warming Potential of Annual Nitrous Oxide and Methane Emissions from Continuously Flooded Rice in Re- 
sponse to Nitrogen Input. Agriculture, Ecosystem and Environment, 177, 10-20.

http://dx.doi.org/10.1016/j.agee.2013.05.011

[33] Adviento-Borbe, M.A., Haddix, M.L., Binder, D.L., Walters, D.A. and Dobermann, A. (2007) Soil Greenhouse Gas Fluxes and Global Warming Potential in Four High-Yielding Maize Systems. Global Change Biology, 13, 1972-1988. http://dx.doi.org/10.1111/j.1365-2486.2007.01421.x

[34] Miller, P.R., McConkey, B., Clayton, G.W., Brandt, S.A., Staricka, J.A., Johnston, A.M., Lafond, G.P., Schatz, B.G., Baltensperger, D.D. and Neill, K.E. (2002) Pulse Crop Adaptation in the Northern Great Plains. Agronomy Journal, 94, 261-272. http://dx.doi.org/10.2134/agronj2002.0261 